\title{
Enhanced Phosphorylation of NMDA Receptor 1 Subunits in Spinal Cord Dorsal Horn and Spinothalamic Tract Neurons after Intradermal Injection of Capsaicin in Rats
}

\author{
Xiaoju Zou, Qing Lin, and William D. Willis \\ Department of Anatomy and Neuroscience, Marine Biomedical Institute, The University of Texas Medical Branch, \\ Galveston, Texas 77555-1069
}

\begin{abstract}
The functional enhancement of NMDA receptors after peripheral tissue injury is proposed to contribute to the sensitization of spinothalamic tract (STT) cells and hyperalgesia. Protein phosphorylation is a major mechanism for the regulation of NMDA receptor function. In this study, Western blots, immunofluorescence double labeling, and the retrograde tracing method were used to examine whether phosphorylation of NMDA receptor 1 (NR1) subunits increases in spinal cord tissue and spinal dorsal horn neurons, especially in STT cells, after injection of capsaicin (CAP) into the glabrous skin of one hindpaw of anesthetized rats. Western blots showed that phosphorylated NR1 protein in spinal cord tissue was increased 30 min after CAP injection. Immunofluorescence double-labeling staining showed no significant difference in the number of the NR1-like immunoreactive neurons in laminae $\mathrm{I}-\mathrm{VII}$ in the lumbosacral segments $\left(\mathrm{L}_{4}-\mathrm{S}_{1}\right)$ on the ipsilateral and the contralateral sides $30 \mathrm{~min}$ after CAP or vehicle
\end{abstract}

injection. However, the numbers of phospho-NR1-like immunoreactive neurons were significantly increased on the ipsilateral side compared with the vehicle injection group. STT cells were labeled by bilateral microinjections of the retrograde tracer fluorogold into the lateral thalamus, including the ventral-posterior lateral nucleus. Immunofluorescence staining was performed at 30,60 , and 120 min after CAP injection or at 30 min after vehicle injection. There was a significant increase in the proportion of STT cells with phosphorylated NR1 subunits compared either with the contralateral side 30 and 60 min after CAP injection or either side of animals after intradermal injection of vehicle. These results provide direct evidence that NMDA receptors in STT cells are phosphorylated after CAP injection.

Key words: NMDA receptor subunit; phosphorylation; STT cell; retrograde tracing; dorsal horn; nociception
Spinothalamic tract (STT) cells transmit nociceptive information from the spinal cord to the thalamus (Willis, 1985; Gybels and Sweet 1989; Willis and Coggeshall, 1991). Extracellular glutamate and aspartate concentrations increase significantly in the spinal cord dorsal horn after peripheral inflammation (Sluka and Westlund, 1992, 1993a; Sorkin et al., 1992; Sorkin and McAdoo, 1993; Sluka and Willis, 1998), and this increase is believed to underlie hyperalgesia and allodynia (Sluka and Westlund, 1993b) by enhancing the excitability of nociceptive dorsal horn neurons, including STT cells (Aanonsen et al., 1990; Dougherty and Willis, 1991, 1992; Dougherty et al., 1992a,b). Intrathecal administration of glutamate agonists such as NMDA elicits nociceptive behavior (Aanonsen and Wilcox, 1987), and spinal cord administration of an NMDA receptor antagonist attenuates hyperalgesia and allodynia (Haley et al., 1990; Ren et al., 1992a,b; Ren and Dubner, 1993; Sluka et al., 1994). At a cellular level, central sensitization of STT cells can be initiated by iontophoretic co-release of NMDA and substance P (cf. Randic et al., 1990; Dougherty and Willis, 1991) and is prevented by an NMDA receptor antagonist (Dougherty et al., 1992a; Rusin et al., 1992, 1993).

Intradermal capsaicin injection is a convenient means to produce central sensitization of STT cells in monkeys and mechanical hyperalgesia and allodynia in humans (LaMotte et al., 1991, 1992; Simone et al., 1991; Torebjörk et al., 1992). The responses of sensitized STT cells to iontophoretically released excitatory amino acids, including NMDA, increase for $\sim 1.5 \mathrm{hr}$ after capsaicin injection (Dougherty and Willis, 1992; Dougherty et al., 1992a). This

\footnotetext{
Received Jan. 24, 2000; revised May 18, 2000; accepted July 3, 2000.

This work supported by National Institutes of Health Grants NS09743 and NS11255. We thank Z. M. Ye, G. Q. Wang, J. H. Du, and J. Wu for technical advice and G. Gonzales for assistance with the illustrations.

Correspondence should be addressed to Dr. William D Willis, Department of Anatomy and Neuroscience, Marine Biomedical Institute, The University of Texas Medical Branch, Galveston, TX 77555-1069. E-mail: wdwillis@ utmb.edu. Copyright (C) 2000 Society for Neuroscience $0270-6474 / 00 / 206989-09 \$ 15.00 / 0$
}

time course parallels closely that of the secondary mechanical allodynia observed in human subjects (LaMotte et al., 1991). Central sensitization of STT cells depends on the activation of several protein kinases (PKs), including PKC, PKG, and PKA (Lin et al., 1996, 1997a,b; Sluka et al., 1997). Similarly, PKC and PKA have been shown to produce a long-lasting enhancement of excitatory responses of dorsal horn neurons in in vitro preparations (Chen and Huang, 1991, 1992; Cerne et al., 1992, 1993; Rusin et al., 1993). The responses of neurons in slices of the trigeminal nucleus caudalis to NMDA are enhanced after injection of PKC into the neurons (Chen and Huang, 1991), and these enhanced responses can be explained by an increased probability of channel openings and a reduction in the voltage-dependent $\mathrm{Mg}^{2+}$ block of the NMDA receptor channels (Chen and Huang, 1992). Such changes in NMDA receptor function may depend on phosphorylation of the NMDA receptors (Raymond et al., 1994; Hatt, 1999). The NMDA receptor 1 (NR1) subunit is phosphorylated by PKC on Ser-890 and -896 and by PKA on Ser-897 (Tingley et al., 1997). Phosphorylation at these sites can be monitored with phosphorylation sitespecific antibodies.

In the present study, phosphorylation of NMDA receptors after intradermal injection of capsaicin was examined in the rat spinal cord, using antibodies that recognize NR1 or phospho-NR1 subunits for Western blots and immunofluorescence double labeling. STT cells were identified by retrograde transport of fluorogold from the lateral thalamus, including the ventral-posterior lateral nucleus. Our results show that there is an increase in phosphorylated NR1 subunits after capsaicin injection and support the idea that NMDA receptors in STT neurons play a role in the transmission of nociceptive information, and that phosphorylation of these receptors contributes to the development of central sensitization of STT cells.

Parts of this paper have been published previously in abstract form (Zou et al., 1999). 


\section{MATERIALS AND METHODS}

A total of 40 male Sprague Dawley rats weighing 250-350 gm were used for this study. All experimental protocols were approved by the Animal Care and Use Committee and were in accordance with the guidelines of the National Institutes of Health and the International Association for the Study of Pain.

Antibodies that recognize NR1 subunits and phospho-NR1 subunits of NMDA receptors were obtained from Upstate Biotechnology (Lake Placid, NY). The phospho-NR1 antibody used is selective for the Ser-897 (PKA) site and has been used to detect the phosphorylation by PKA of NR1 subunits expressed in fibroblasts (Tingley et al., 1997). A similar approach has been used to demonstrate the phosphorylation of Glu receptor 1 subunits of AMPA receptors in hippocampal neurons by calcium/ calmodulin-dependent kinase II (Mammen et al., 1997)

Western blotting. Ten anesthetized Sprague Dawley rats were killed at 30 min after intradermal capsaicin (CAP) or vehicle injection into the glabrous skin of one hind paw. Spinal cord segments $\mathrm{L}_{4}-\mathrm{S}_{1}$ were removed and put immediately into liquid nitrogen. Spinal cord tissue was homogenized in $50 \mathrm{~mm}$ Tris buffer. The homogenate was centrifuged twice at $10,000 \times$ $g$ for $10 \mathrm{~min}$ at $4^{\circ} \mathrm{C}$. The supernatant was decanted from the pellet and used for all Western blot analyses. The concentration of protein in the homogenate was measured using a BCA kit (Pierce, Rockford, IL). Equa amounts of protein $(60 \mu \mathrm{g})$ were fractionated by $7.5 \%(\mathrm{w} / \mathrm{v})$ SDS-PAGE and transferred onto a polyvinylidene difluoride membrane and then incubated with primary monoclonal antibody to NR1 (1:1000; Upstate Biotechnology) or immunoaffinity-purified antibody to phospho-NR1 (1:1000; Upstate Biotechnology) overnight at $4^{\circ} \mathrm{C}$. The blots were washed three times for $30 \mathrm{~min}$ each with washing buffer and then incubated with horseradish peroxidase conjugated with IgG (Santa Cruz Biotechnology, San Francisco, CA) diluted in $2.5 \%$ (w/v) nonfat milk in washing buffer. The membranes were washed with buffer three times for $30 \mathrm{~min}$ and enhanced with a chemiluminesence reagent (ECL kit; Amersham Pharmacia Biotech, Arlington Heights, IL). The blots were exposed to autoradiographic film (Eastman Kodak Co., Rochester, NY), and the intensity of immunoreactive bands of interest was quantified using densitometric scanning analyses.

Immunofluorescence. Ten animals anesthetized by sodium pentobarbital $(50 \mathrm{mg} / \mathrm{kg}$, i.p. $)$ were divided into two groups. Fifty microliters of capsaicin (1\% suspended in a vehicle emulsion) or vehicle (3\%) were injected intradermally into the glabrous skin of the hindpaw on one side. At $30 \mathrm{~min}$ after CAP or vehicle injection, the animals were perfused through the left ventricle with $100 \mathrm{ml}$ of saline followed by $500 \mathrm{ml}$ of $4 \%$ paraformaldehyde in $0.1 \mathrm{M}$ phosphate buffer $\left(\mathrm{PB}, \mathrm{pH} 7.4,4^{\circ} \mathrm{C}\right)$. Segments $\mathrm{L}_{4}-\mathrm{L}_{5}$ of the spinal cord were removed and kept in the same fixative for $4 \mathrm{hr}$ and then cryoprotected overnight in $30 \%$ sucrose in $0.1 \mathrm{M}$ PB. Frozen sections were cut at $10 \mu \mathrm{m}$ on a cryostat and collected on gelatinized slides. Immunofluorescence double labeling was performed for the NR1 or phosphoNR1subunits by the avidin-biotin-peroxidase (ABC) method on the same sections. In brief, the sections were incubated in $10 \%$ normal goat serum with $0.3 \%$ Triton X-100 in PBS for $1 \mathrm{hr}$ and then incubated overnight at $4^{\circ} \mathrm{C}$ in $100 \mu \mathrm{l}$ of PBS containing a mixture of mouse monoclonal NR1 antibody (1:1000; Upstate Biotechnology) and rabbit immunoaffinitypurified phospho-NR1 antibody (1:1000; Upstate Biotechnology). The sections were washed and transferred to the secondary antibody solution, containing goat anti-mouse-FITC (1:200; Sigma, St. Louis, MO) and goat anti-rabbit Texas Red (1:200; Vector Laboratories, Burlingame, CA) with $5 \%$ sheep serum, and incubated for $1 \mathrm{hr}$ at room temperature. Slides were washed and mounted with mounting medium (Vector). To confirm the specificity of the primary antibody, in all experiments the specificity of immunolabling and the absence of antibody cross-reaction in doublestaining experiments were controlled by omission of the primary antibodies. Because staining intensity might vary between experiments, control sections were included in each run of staining.

Labeled sections were analyzed and examined by fluorescence and confocal microscopy to characterize NR1 and phospho-NR1 immunofluorescence, using an Olympus Optical (Tokyo, Japan) microscope equipped for epifluorescence and an Olympus Fluoview confocal microscope. When only the standard fluorescence filters (first the fluorescein and then the Texas Red filter) were available, the separately digitized images of a specific field were taken by automatic mode exposure to obtain a pair of two different color images for NR1- and phospho-NR1-labeled neurons, respectively. The sections were examined at $20 \times$ magnification. For quantification, profiles were considered positive only when they were clearly labeled. Neurons with distinct nuclear staining were counted in two subregions, the superficial layers (laminae I-III) and deeper layers (laminae IV-VII) of the dorsal horn. The average number of NR1-LI neurons or phospho-NR1-LI neurons per section counted within laminae I-V II from the $\mathrm{L}_{4}-\mathrm{L}_{5}$ segments in 20 to 25 sections per animal was calculated and averaged. Five animals were included in each group. Results from two independent experiments were averaged. All data are expressed as mean \pm SE. Statistical analysis was performed using paired $t$ tests, and $p<0.05$ was considered statistically significant.

Retrograde tracing and immunofluorescence. Animals were anesthetized with sodium pentobarbital $(50 \mathrm{mg} / \mathrm{kg}$, i.p.). Bilateral injections $(50 \sim 100 \mathrm{nl})$ of $4 \%$ fluorogold (FG; Fluorochrome, Inc.) in distilled water were made into the region of the ventral-posterior lateral nucleus of the thalamus (VPL), using a micropipette attached to the needle of a $5 \mu$ l Hamiliton

Table 1. Relative density (Mean \pm SE) of NR1 receptor protein and phospho-NR1 receptor protein at $\mathrm{L}_{4}-\mathrm{S}_{1}$ segments of spinal cord

\begin{tabular}{lll} 
Group & NR1 receptor protein & Phospho-NR1 receptor protein \\
\hline $0.5 \mathrm{hr}$ CAP & $4.34 \pm 0.33$ & $3.92 \pm 0.57^{*}$ \\
$0.5 \mathrm{hr}$ vehicle & $4.07 \pm 0.21$ & $1.97 \pm 0.37$
\end{tabular}

* Significantly different from control $(t$ test $), p<0.001$.

(Reno, NV) microsyringe. Four injections were made on each side using coordinates obtained from a stereotaxic atlas of the rat brain (Paxinos and Watson, 1986). All animals were given postoperative care. After a survival period of 3-4 d, animals were reanesthetized with sodium pentobarbital $(50 \mathrm{mg} / \mathrm{kg}$, i.p.), and then a volume of $50 \mu \mathrm{l}$ of $3 \%$ CAP (suspended in a vehicle emulsion) or the same volume of $3 \%$ vehicle was injected intradermally into the glabrous skin of the hindpaw on one side. The animals were perfused transcardially with $100 \mathrm{ml}$ of $0.9 \%$ saline followed by $500 \mathrm{ml}$ of $4 \%$ paraformaldehyde in $0.4 \mathrm{M} \mathrm{PBS}, \mathrm{pH} 7.4,4^{\circ} \mathrm{C}$, at 30,60 , or $120 \mathrm{~min}$, respectively, after CAP injection or at $30 \mathrm{~min}$ after vehicle injection. Brain and spinal cord segments $\mathrm{L}_{4}-\mathrm{S}_{1}$ were cut transversely on a freezing microtome at 40 and $10 \mu \mathrm{m}$, respectively. The locations of the FG injections in the thalamus were identified by fluorescence microscopy. Spinal cord sections were collected on gelatinized slides. Immunofluorescence double labeling was performed for the NR1 or phospho-NR1 subunits by the ABC method on the same sections. The processing was the same as described above.

The stained sections were examined, and profiles of the retrogradely labeled STT cells were counted as described above for fluorescence microscopy. Indirect immunofluorescence images of labeled samples were acquired by laser-scanning confocal microscopy (Olympus) and photographed using an image recorder. Counts were obtained for cell bodies in the dorsal horn that contained the FG retrograde tracer, those STT cells that had immunoreactivty only to NR1 antibody, and those that contained both FITC and Texas Red fluorescence, which were therefore immunoreactive to both NR1 and phospho-NR1 antibodies. Twenty-five sections that were separated by at least $50 \mu \mathrm{m}$ between sections and collected, respectively, from the $\mathrm{L}_{4}$ and $\mathrm{L}_{5}$ and the $\mathrm{L}_{6}$ and $\mathrm{S}_{1}$ segments, were selected from each animal for counting and averaging cell numbers. The percentages of all labeled STT neurons that expressed NR1 or also phospho-NR1

A

1/2 h CAP $1 / 2 \mathrm{~h}$ vehicle

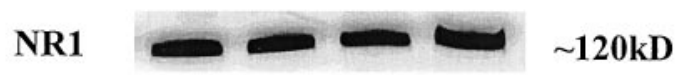

Phospho-NR1

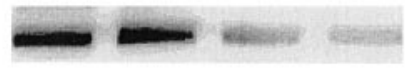

$\sim 120 \mathrm{kD}$

B

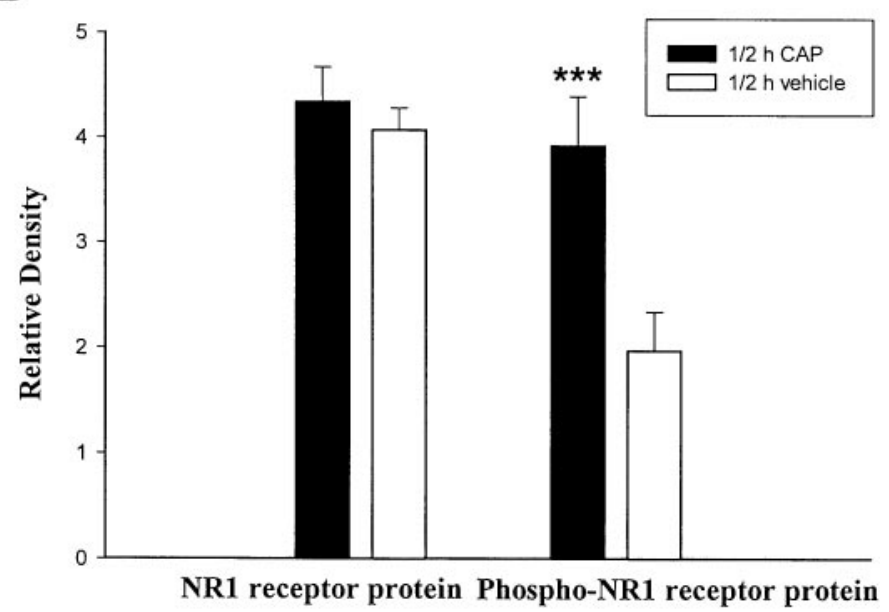

Figure 1. Western analysis of spinal cord tissue $\left(\mathrm{L}_{4}-\mathrm{S}_{1}\right)$ in rats with NR1 receptor and phospho-NR1 receptor antibody 30 min after CAP or vehicle injection, respectively. The data are from five different animals in each of two groups. $A$, Western blots in representative experiments (5 rats with CAP injections and 5 with vehicle injections). Numbers on the right indicate positions of molecular weight markers in kilodaltons. $B$, Bar graph summarizing the relative density of immunoblots of rat spinal cord tissue. The amount of phospho-NR1 receptor protein was significantly increased 30 min after the CAP injection compared with $30 \mathrm{~min}$ after the vehicle injection. $n=5$ for each groups. ${ }^{* * *} p<0.001$. 

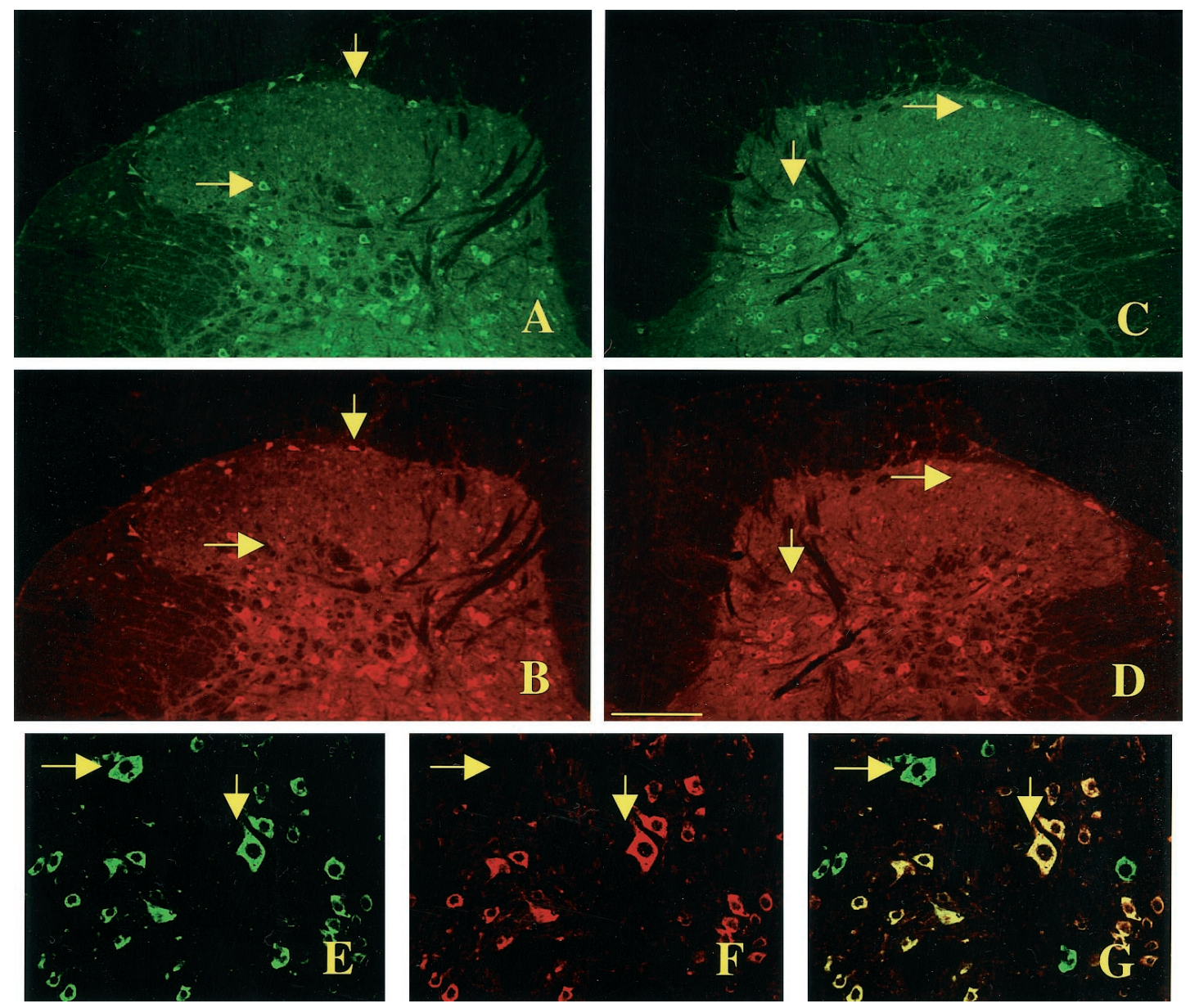

Figure 2. Immunofluorescence imaging showing the distribution and coexistence of NMDA NR1-LI neurons $(A, C, E)$ and phospho-NR1-LI neurons $(B, D, F)$ in the dorsal horn of rats on the ipsilateral $(A, B)$ and contralateral $(C, D)$ sides 30 min after CAP injection. Notice the neurons that were positive for NR1 $(A, C$, vertical arrows), as well as for phospho-NR1 $(B, D)$, and other neurons (horizontal arrows) that were positive for NR1 but were phospho-NR1-negative. $A$, The dorsal horn on the left (ipsilateral to the CAP injection) contains many NR1-LI neurons. $B$, The equivalent region from the same section contains many phospho-NR1-LI neurons, which are most densely packed in the superficial laminae and especially lamina V. $C$, The dorsal horn on the right (contralateral to the CAP injection) from the same section also contains many NR1-LI neurons. $D$, The equivalent region on the right (contralateral to the CAP injection) contains relatively few phospho-NR1-LI neurons. $E-G$, Higher magnification of the immunofluorescence confocal images shown in $A$ and $B$ demonstrates a morphologically identified neuron that was positive for NMDA NR1 ( $E$, $\downarrow$ ), as well as for phospho-NR1 $(F, \downarrow)$. Coexistence of NR1 and phospho-NR1 in the same neuron could be seen $(G, \downarrow)$. Note that some neurons express NR1 alone but not phospho-NR1 $(E-G, \rightarrow)$. Scale bar: $A-G, 150 \mu \mathrm{m} ; E-H, 50 \mu \mathrm{m}$.

Table 2. Number (Mean \pm SE) of NR1-LI neurons and Phospho-NR1-LI neurons per section in laminae

I-VII of dorsal horn at $\mathrm{L}_{4}-\mathrm{L}_{5}$ segments

\begin{tabular}{|c|c|c|c|c|}
\hline \multirow[b]{2}{*}{ Group } & \multicolumn{2}{|c|}{ NR1-LI neurons ${ }^{a}$} & \multicolumn{2}{|c|}{ Phospho-NR1-L1 neurons ${ }^{a}$} \\
\hline & I & $\mathrm{C}$ & I & $\mathrm{C}$ \\
\hline $0.5 \mathrm{hr}$ CAP & $113.07 \pm 4.14$ & $109.72 \pm 3.01$ & $97.36 \pm 4.70^{*}$ & $65.87 \pm 3.32$ \\
\hline $0.5 \mathrm{hr}$ vehicle & $103.17 \pm 3.15$ & $117.01 \pm 4.10$ & $66.06 \pm 2.77$ & $72.23 \pm 3.68$ \\
\hline
\end{tabular}

${ }^{a}$ I, Ipsilateral to injection side; $\mathrm{C}$, contralateral to injection side.

* Significantly different from control $(t$ test $), p<0.01$.

subunits from each side in the four groups of animals were counted. Averages are given as mean \pm SE. Paired $t$ tests were used to compare immunofluorescence measures in each ipsilateral side with its respective contralateral side after CAP or vehicle injection. For multiple comparisons between 30, 60, and $120 \mathrm{~min}$ after CAP injection and vehicle-injected animals in the proportion of STT cells with phosphorylated NR1 subunits, one-way ANOVA, followed by post hoc $t$ tests, was used. The criterion for statistical significance was $p<0.05$.

\section{RESULTS}

\section{Western blotting}

The relative density of immunoblots of NR1 and phospho-NR1 subunit protein from rat spinal cord tissue after intradermal CAP injection was compared with that after vehicle injection (Table 1).
There was no significant change in the immunoblots for NR1 subunits $(p>0.05)$, but the immunoblots for phospho-NR1 showed a significant increase in protein between the two groups $(p<0.001$; Fig. 1).

\section{Immunofluorescence}

The distribution of the NR1-like immunoreactive (NR1-LI) and phospho-NR1-like immunoreactive (phospho-NR1-LI) neurons in the lumbar spinal cord of rats with a unilateral CAP or vehicle injection is illustrated in Figure 2. The fluorescence signals for antibodies to NR1 or phospho-NR1 subunits, which specifically recognize the $\mathrm{C}$-terminal region, were localized in the cytoplasm and dendrites and did not enter the nucleus. Some individual 

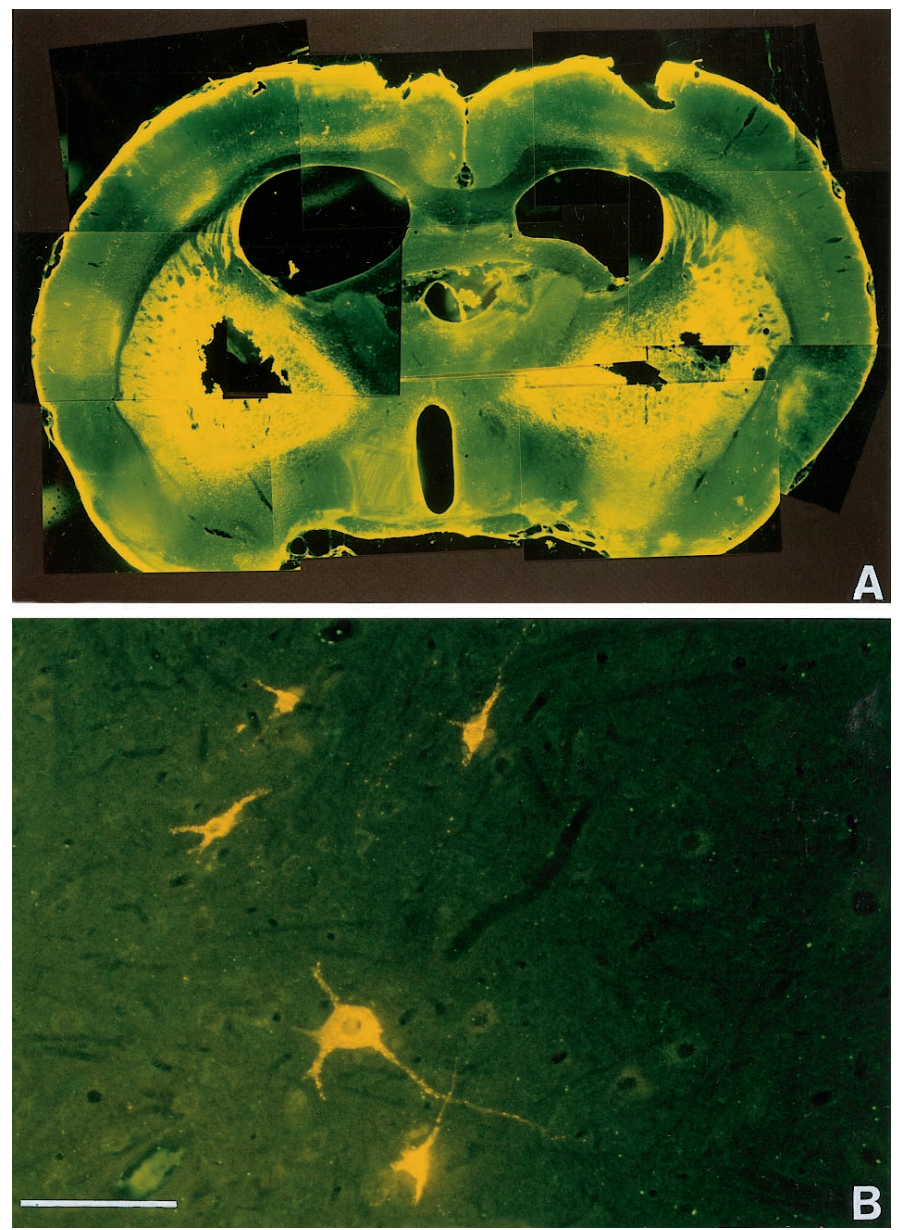

Figure 3. Retrograde labeling of STT cells by bilateral microinjections of fluorogold into the region of the VPL. $A$, Photomontage illustrating the location of bilateral fluorogold injections in the lateral thalamus, including the VPL nucleus. Note that the injection did not spread into the hypothalamus. There were necrotic cores in the centers of the injection sites. $B$, Labeled STT cells in the deep dorsal horn of the spinal cord. Scale bar, $250 \mu \mathrm{m}$.

neurons contained just NR1-LI, whereas others stained for both NR1-LI and phospho-NR1-LI (Fig. $2 E-G$ ). There was no difference in the distribution of NR1-LI neurons between the two sides of the dorsal horn in either CAP injection or vehicle injection groups (Fig. 2A,C). However, dense phospho-NR1 staining was found to localize mainly on the side ipsilateral to the CAP injection in lateral spinal lamina $\mathrm{V}$ (Fig. 2B,D).

Table 2 summarizes counts from each animal for the number of NR1-LI neurons and phospho-NR1-LI neurons in laminae I-VII of the $\mathrm{L}_{4}-\mathrm{L}_{5}$ segments. The counts of NR1-LI neurons did not show a significant difference between the two sides in laminae I-V II after CAP injection (Table 2). However, there was a significant increase in the number of phospho-NR1-LI neurons on the side ipsilateral to the CAP injection in laminae I-VII compared either with the side contralateral to the CAP injection or with either side of animals after intradermal injection of vehicle. The number of phospho-NR1-LI neurons was increased on the side ipsilateral to the CAP injection ( $97.36 \pm 4.70$ neurons per section) compared with the side contralateral to CAP injection (65.87 \pm 3.32) and with the two sides in animals injected with vehicle $(66.01 \pm 2.77$ and $72.23 \pm 3.68)$, respectively.

\section{Retrograde tracing and immunofluorescence}

Retrogradely labeled cell bodies were observed bilaterally throughout the dorsal horn of the lumbar enlargement of spinal cord after injections of the fluorescent retrograde tracer FG into the region of the VPL nucleus bilaterally (Fig. 3). A small number of neurons containing the retrograde tracer were also observed in the ventral horn. They were not analyzed in this report.

Approximately $80 \%$ of the retrogradely labeled cells containing the FG tracer within laminae I-VII in all animal groups were found to be immunoreactive to NR1 antibodies, because they contained both FG and FITC fluorescence (Figs. 4, 5). There was no difference in the distribution of these neurons between the two sides; therefore, they were compared with STT cells in vehicleinjected rats (Fig. 5). There was no significant difference $(p>0.05)$ in the proportion of retrogradely labeled neurons immunoreactive to NR1 antibodies between the two sides and between the two groups (Fig. $6 A$, Table 3 ). Retrogradely labeled neurons immunoreactive to both NR1 and phospho-NR1 antibodies, and therefore containing FG, FITC, and Texas Red fluorescence, were also localized in laminae I-III, V, and X on both sides of the spinal cord. However, after a unilateral CAP injection into a hindpaw, more neurons showing phospho-NR1 subunits were seen on the side ipsilateral to the injection in laminae I-VII. There was a significant increase in the proportion of these STT cells compared either with the contralateral side 30 and 60 min after CAP injection or with either side in animals in which vehicle was injected intradermally (Fig. 6B). The proportion of STT cells with phosphorylated NMDA receptors was 81 and $76 \%$ on the ipsilateral side compared with 48 and $53 \%$ on the contralateral side 30 and $60 \mathrm{~min}$ after capsaicin injection (Table 3$)$. There was no increase $(p>$ $0.05)$ in the number of STT cells that were immunoreactive for phospho-NR1 antibodies on the side ipsilateral $(62 \%)$ compared with the side contralateral $(60 \%)$ to the injection 120 min after CAP injection (Figs. 6B, 7; Table 3). Table 3 summarizes data for the proportion of labeled STT neurons that expressed NR1 subunits and also phospho-NR1 subunits on each side in the four groups of animals. In addition, it was found that the proportion of STT cells immunoreactive to phospho-NR1 antibodies in the $\mathrm{L}_{6}-\mathrm{S}_{1}$ segments was greater than in the $\mathrm{L}_{4}-\mathrm{L}_{5}$ segments in laminae I-V II on the side ipsilateral of CAP injection in the 30 min group but was not different at $60 \mathrm{~min}$ (Fig. $8 \mathrm{~A}$ ). A comparison between laminae I-III and laminae IV-V II showed no significant difference in the proportions of STT cells immunoreactive to phospho-NR1 antibodies at 30 and 60 min after CAP injection (Fig. 8B).

\section{DISCUSSION}

This study demonstrates the presence of NR1 subunits of NMDA receptors in neurons of the rat lumbosacral spinal cord and specifically in $>80 \%$ of STT cells of laminae I-V II. Furthermore, after intradermal injection of capsaicin, there is a significant increase in the amount of phospho-NR1 protein and in the number of dorsal horn neurons, including STT cells, which clearly contain phosphoNR1 subunits. These observations support a role of NMDA receptors in synaptic transmission in the dorsal horn and the idea that the phosphorylation of NR1 subunits is related to activitydependent changes of excitability of STT cells after strong noxious stimulation.

The reaction products of antibodies that recognize the C-terminal region of NR1 or phospho-NR1 subunits were localized to the cytoplasm of the soma-dendritic regions of spinal neurons. This is consistent with the three transmembrane segment models of NR1 subunits, in which the $\mathrm{C}$ terminus resides on the cytoplasmic side of the surface membrane (Wood et al., 1995; Dingledine et al., 1999). However, part of the NR1 subunit protein appears to be well away from the surface membrane, suggesting that much of the subunit protein has not been inserted into the membrane (cf. Ehlers et al., 1995; Ye and Westlund, 1996). These NR1 subunits may be ready for insertion or perhaps are transported along the axons (Aoki et al., 1998; Commons et al., 1999) for insertion in synaptic terminal membrane.

Our results show that NR1-LI STT cells are widely distributed in laminae I-V II and X. This is consistent with previous descriptions of the distribution of retrogradely labeled rat STT cells (Burstein et al., 1990) and of neurons that contain NR1 mRNA, as shown by in situ hybridization experiments (Furuyama et al., 1993). The 

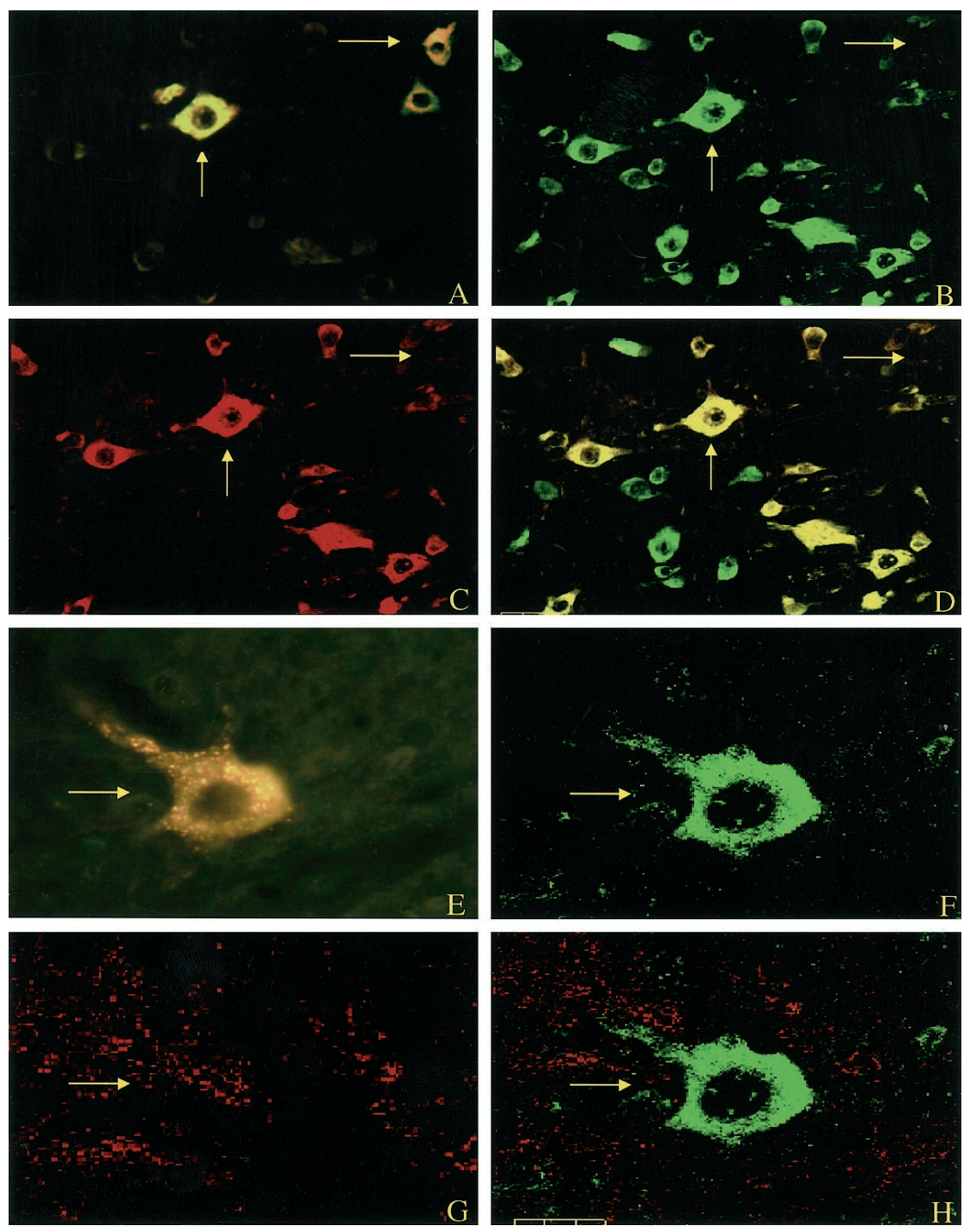

Figure 4. Confocal immunofluorescence images of STT cells in the dorsal horn double labeled for NR1 and phospho-NR1. Yellow fluorescence, retrograde tracer fluorogold; green fluorescence, NR1; red fluorescence, phospho-NR1. $A-D$, Two STT neurons labeled by FG $(A$, yellow, $\uparrow, \rightarrow)$. One was positive for $\mathrm{NR} 1(B, \uparrow)$ as well as for phospho-NR1 $(C, \uparrow)$. NR1 and phosphoNR1 coexisted in the same cell $(D, \uparrow)$. Another STT cell did not express either NR1 or phospho-NR1 $(A, D$, $\rightarrow)$. Note that the immunostained product for NR1, with a specific antibody that recognizes the C-terminal region, is localized in the cytoplasm of the cell body and dendrites as well as near the surface membrane. $E-H$, One STT cell labeled by FG $(E$, yellow, $\rightarrow)$ that expressed NR1 $(F, \rightarrow)$ but not phospho-NR1 is also shown $(G, H, \rightarrow)$. Scale bar: $A-D, 50 \mu \mathrm{m} ; E-H, 20 \mu \mathrm{m}$.
NR1 subunit is a key component of NR1-3 heteromeric NMDA receptors and is believed to be part of the composition of native NMDA receptors (Sugihara et al., 1992; Ishii et al., 1993; Hollmann and Heinemann, 1994; Laurie et al., 1995; Mori and Mishina, 1995). Previous studies, using electrophysiological and pharmacological approaches to demonstrate a role of NMDA receptors in synaptic transmission in the dorsal horn, have generally provided only indirect evidence for the site of action of excitatory amino acids (Davies and Lodge, 1987; Dickenson and Sullivan, 1987; Dougherty and Willis, 1992; Nagy et al., 1993; Rivot et al., 1999) (cf. Bardoni et al., 1998); therefore, it is often uncertain whether the NMDA receptors targeted by the drug are on the neuron from which recordings are being made or on primary afferent (Liu et al., 1994) or interneuronal terminals. The present investigation and a previous one from our group (Ye and Westlund, 1996) support the interpretation that at least part of the responses of STT cells to iontophoretic release of NMDA are attributable to a postsynaptic action. The excitatory action on STT cells produced by ionophoretic release of NMDA presumably reflects a partial relief of the $\mathrm{Mg}^{2+}$ block by the depolarizing drive that is responsible for the usual background activity of most primate STT cells (cf., Dougherty and Willis, 1991, 1992). Alternatively, activation of protein kinases may be responsible, perhaps by maintaining a background level of phosphorylation of excitatory amino acid receptors (Chen and Huang, 1992; Cerne et al., 1993; Li and Zhuo, 1998), as suggested by the presence of many phospho-NR1-LI STT cells even in vehicle-injected rats.
There was an increase in the number of STT cells that could be recognized to contain phospho-NR1 subunits after intradermal injection of capsaicin. This change is consistent with a role of NR1 subunits in activity-dependent synaptic plasticity during nociceptive processing in the dorsal horn. The phosphorylation sitespecific antibodies that were used recognize the NR1 protein only when a specific serine residue is phosphorylated, in this case Ser-897. The increase in the number of phospho-NR1-LI STT cells occurred at 30 and 60 min after capsaicin injection, a time when there is central sensitization of STT cells (Dougherty and Willis, 1992; Dougherty et al., 1992a). These findings are agreement with the observation that phosphorylation of NMDA receptors occurs in other types of neurons, such as hippocampal neurons, and that the phosphorylation may lead to an enhancement in responses to NMDA (Wang et al., 1996; Christie et al., 1999). In vitro studies of spinal cord dorsal horn neurons are consistent with this idea (Chen and Huang, 1991, 1992; Cerne et al., 1992, 1993; Rusin et al., 1993).

Protein phosphorylation is a major mechanism by which glutamate receptor function is regulated (Dingledine et al., 1999). Serine/threonine phosphorylation of NMDA receptors mediated by PKC and PKA occurs on different serine residues (Leonard and Hell, 1997; Tingley et al., 1997). There can also be phosphorylation of NMDA receptors by tyrosine kinases (Rostas et al., 1996), such as Src (Yu et al., 1997; Yu and Salter, 1999). There is evidence that the potentiation of NMDA receptor activity by $\mathrm{PKC}$ is not by direct phosphorylation of the receptors but rather by phosphorylation of other associated proteins (Zheng et al., 1999). In the 


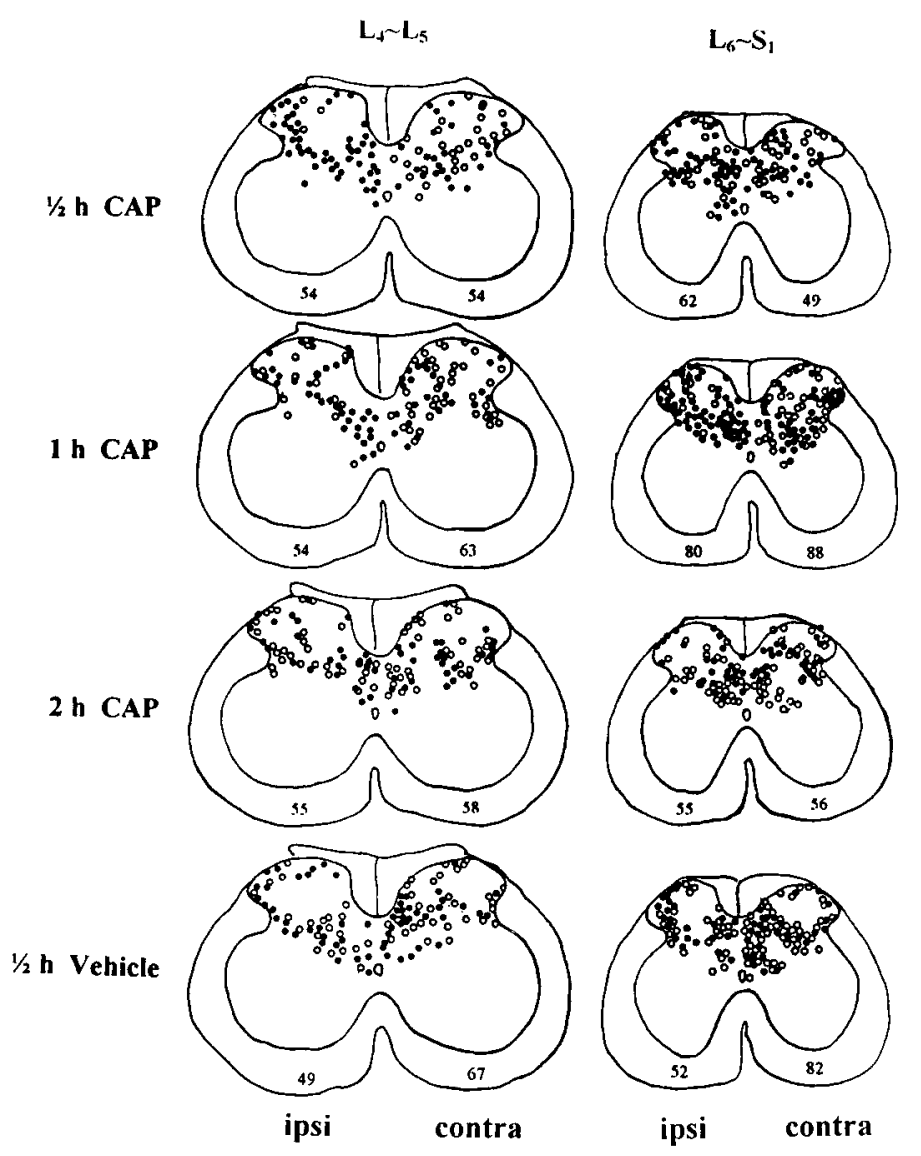

Figure 5. Location and number of NR1-LI and phospho-NR1-LI STT cells on each side in one animal per group. Black dots indicate STT cells that showed both NR1-LI and phospho-NR1-LI, and open dots indicate those that had only NR1-LI. Note that $\sim 80 \%$ of the retrogradely labeled cells containing the FG tracer within laminae I-VII in all animal groups were found to be immunoreactive to NR1 antibodies, and there was no difference in the distribution of these neurons between the two sides. There was a significant increase in the proportion of STT cells with phosphorylated NMDA receptors compared either with the contralateral side 30 and $60 \mathrm{~min}$ after CAP injection or with either side of animals after intradermal injection of vehicle. ipsi, Ipsilateral to injection; contra, contralateral to injection.

present experiments, the phosphorylation site recognized by the antibodies that were used was Ser-897, the PKA phosphorylation site. Previous work by our group has shown that PKA is activated after intradermal injection of capsaicin (Lin et al., 1997b; Sluka et al., 1997); therefore, it is possible that the enhanced responses of NMDA receptors on STT cells are the result of enhanced phosphorylation of NR1 subunits by PKA. Recent experiments in our laboratory indicate that activation of PKA by microdialysis administration of forskolin into the dorsal horn enhances the responses of primate STT cells to noxious pinch but not to innocuous brushing of the skin (Lin et al., 1998). By contrast, activation of PKC by administration of phorbol ester enhances the responses of these cells to brushing but not to pinch (Lin et al., 1996). Administration of the NMDA receptor antagonist DL-2-amino-7-phosphonoheptanoic acid does not affect the responses of STT cells to brushing but does substantially reduce the responses to pinch (Dougherty et al., 1992a). In other words, NMDA receptors are involved in the responses of STT cells to noxious but not to innocuous mechanical stimuli. Therefore, enhancement of the responses of these neurons to NMDA is consistent with a role of PKA activation in the development of mechanical hyperalgesia after intradermal capsaicin injection. The mechanical allodynia is more likely the result of the action of PKC on non-NMDA glutamate receptors. An unexplained finding is that the enhanced phosphorylation of NR1 subunits lasted $<2 \mathrm{hr}$. This time course more closely resembles that
A
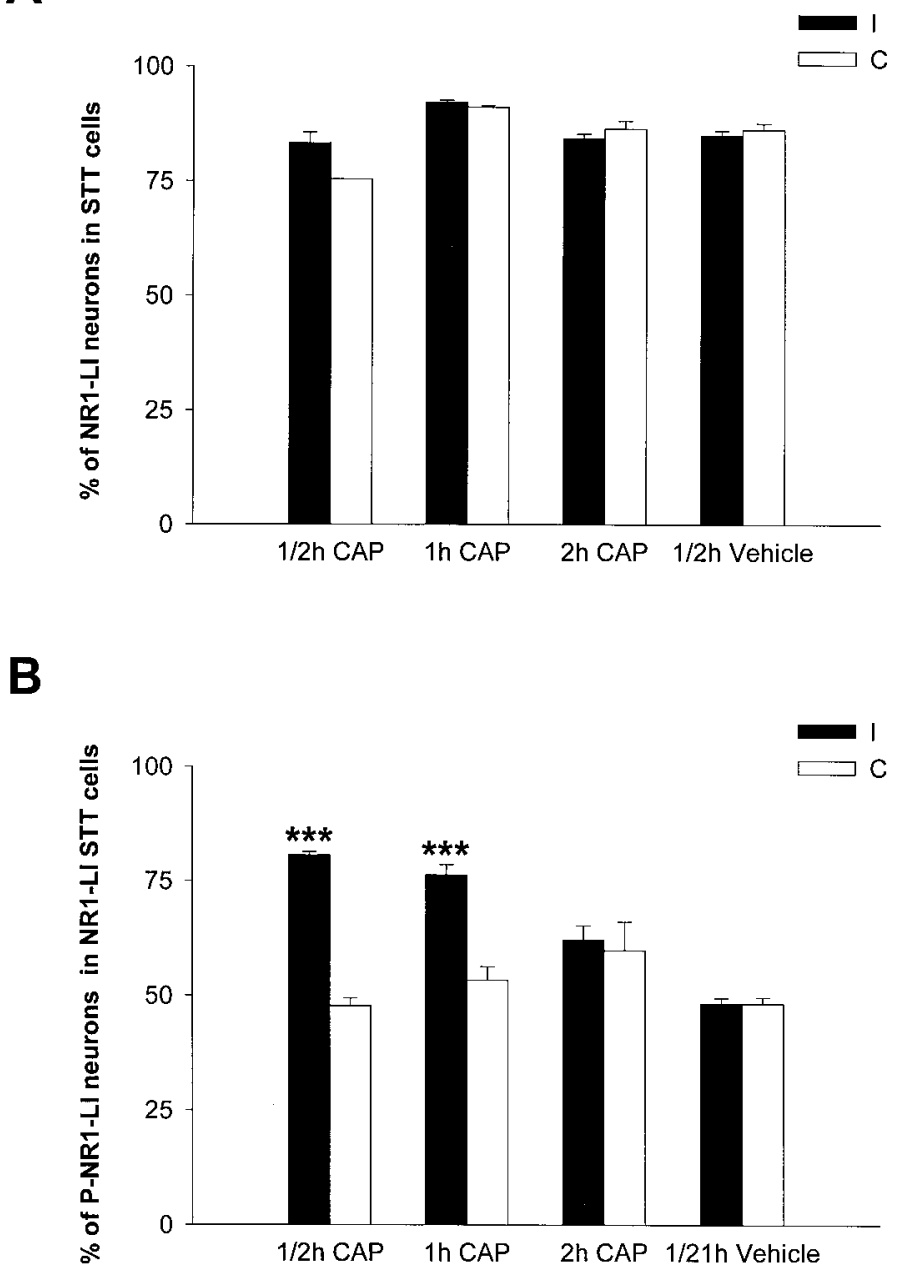

Figure 6. A, Bar graph showing the proportion of NR1-LI STT cells in laminae I-VII in the $\mathrm{L}_{4}-\mathrm{S}_{1}$ segments on the ipsilateral and contralateral sides in both CAP- and vehicle-injected groups. There was no significant difference in the proportion of STT cells with NR1 receptors. $B$, Bar graph showing the proportion of phospho-NR1-LI STT cells in laminae I-V II in the $\mathrm{L}_{4}-\mathrm{S}_{1}$ segments on the ipsilateral and contralateral sides in both CAPand vehicle-injected groups. There was a significant increase in the proportion of STT cells with phosphorylated NMDA receptors compared either with the contralateral side 30 and 60 min after CAP injection or with either side after the vehicle injection. ${ }^{* *} p<0.001$.

of secondary mechanical allodynia than mechanical hyperalgesia in humans given an injection of capsaicin (LaMotte et al., 1991). However, our ability to recognize small changes in phosphorylation with the techniques available is limited. Another puzzling observation is that there was a larger proportion of phospho-NR1-LI STT cells in the $\mathrm{L}_{6}-\mathrm{S}_{1}$ segments than in the $\mathrm{L}_{5}-\mathrm{L}_{6}$ segments $30 \mathrm{~min}$ after capsaicin injection. The injections were made in skin on the plantar surface of the foot that belongs to the $\mathrm{L}_{4}-\mathrm{L}_{5}$ dermatomes (Takahashi et al., 1994). It appears that phosphorylation of NR1 subunits was more effective in STT cells that supply an area of skin that is likely to develop secondary mechanical hyperalgesia than in STT cells with receptive fields centered at the injection site.

On the basis of these observations, we propose the following sequence of events as central sensitization of STT cells develops after capsaicin injection. The capsaicin strongly activates nociceptors containing vanilloid receptor-1 receptors (Tominaga et al., 1998). The terminals of these nociceptors and the interneurons that they excite release excitatory amino acids, including glutamate and aspartate (Sorkin and McAdoo, 1993), as well as peptides, such as substance P (Gamse et al., 1979), at synapses in the dorsal horn. These events result in a prolonged increase in the excitability of nociceptive dorsal horn neurons, including STT cells (Dougherty 
Table 3. Mean percentage ( \pm SE) of NR1-LI STT cells and phospho-NR1-LI STT cells in laminae I-VII of dorsal horn at $\mathrm{L}_{\mathbf{4}}-\mathrm{S}_{\mathbf{1}}$ segments

\begin{tabular}{|c|c|c|c|c|}
\hline \multirow[b]{2}{*}{ Group } & \multicolumn{2}{|c|}{$\%$ NR1-LI STT cells ${ }^{a}$} & \multicolumn{2}{|c|}{$\%$ Phospho-NR1-LI STT cells ${ }^{a}$} \\
\hline & I & $\mathrm{C}$ & I & $\mathrm{C}$ \\
\hline $0.5 \mathrm{hr}$ CAP & $83.3 \pm 2.43$ & $75.5 \pm 1.51$ & $80.6 \pm 0.73^{*}$ & $47.7 \pm 1.74$ \\
\hline $1 \mathrm{hr}$ CAP & $92.9 \pm 0.49$ & $91.2 \pm 0.42$ & $76.3 \pm 2.30^{*}$ & $53.3 \pm 2.97$ \\
\hline $2 \mathrm{hr}$ CAP & $84.4 \pm 0.99$ & $86.5 \pm 1.79$ & $62.1 \pm 3.17$ & $59.8 \pm 6.27$ \\
\hline $0.5 \mathrm{hr}$ vehicle & $85.3 \pm 1.11$ & $86.3 \pm 1.41$ & $48.2 \pm 1.24$ & $48.2 \pm 1.34$ \\
\hline
\end{tabular}

$\overline{{ }^{a} \text { NR1-LI STT cells }=(\mathrm{NR} 1-\mathrm{LI} \text { STT cells/total STT cells }) \times 100 ; \text { phospho-NR1-LI STT cells }=\text { [phospho-NR1-LI STT }}$ cells/(NR1-LI STT cells + phospho-NR1-LI STT cells)] $\times 100$. I, Ipsilateral to injection side; C, contralateral to injection side.

* Significantly different from control $(t$ test $), p<0.001$.

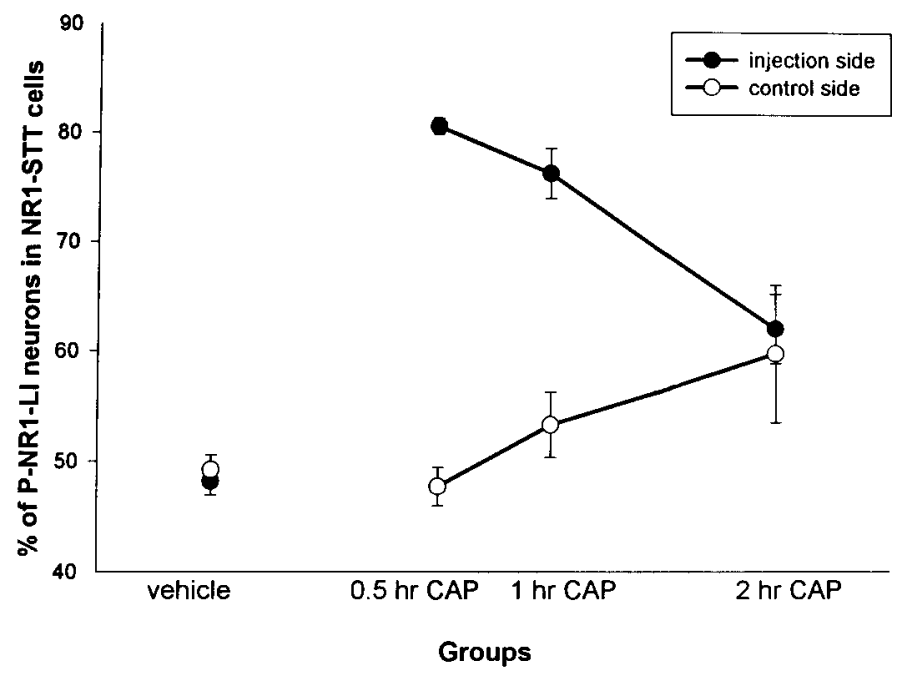

Figure 7. Time course analysis of the proportion of phospho-NR1-LI STT cells between the injection side and contralateral side in both CAP- and vehicle-injected groups in laminae I-V II in the $\mathrm{L}_{4}-\mathrm{S}_{1}$ segments. Note that phosphorylation of NR1 peaked as early as $30 \mathrm{~min}$ after CAP injection. Two hours after CAP injection, there was no significant difference between the ipsilateral and contralateral sides.

and Willis, 1991), by influx of $\mathrm{Ca}^{2+}$ through NMDA channels and voltage-gated calcium channels (Sluka, 1997) and by activation of excitatory G-protein-coupled membrane receptors, such as neurokinin-1 receptors (Dougherty et al., 1994) and group I metabotropic glutamate receptors (Neugebauer et al., 1999). This results in the activation of signal transduction cascades in these neurons (Lin et al., 1996, 1997a,b; Sluka et al., 1997). The present study shows that NR1 subunits of NMDA receptors in STT cells are then phosphorylated, presumably by PKA. The increase in number of phospho-NR1-LI STT cells has a time course that parallels central sensitization of STT cells and at least the initial stages of secondary mechanical hyperalgesia. Our results offer morphological support for the idea that NMDA receptors play an important role in the central sensitization of STT neurons that follows an intradermal capsaicin injection.

\section{REFERENCES}

Aanonsen LM, Wilcox GL (1987) Nociceptive action of excitatory amino acids in the mouse: effects of spinally administered opioids, phencyclidine and sigma agonists. J Pharmacol Exp Ther 243:9-19.

Aanonsen LM, Lei S, Wilcox GL (1990) Excitatory amino acid receptors and nocicpetive neurotransmission in rat spinal cord. Pain 41:309-321.

Aoki C, Bredt DS, Fenstemaker S, Lubin M (1998) The subcellular distribution of nitric oxide synthase relative to the NR1 subunit of NMDA receptors in the cerebral cortex. Prog Brain Res 118:83-97.

Bardoni R, Magheriini PC, MacDermott AB (1998) NMDA EPSCs at glutamatergic synapses in the spinal cord dorsal horn of the postnatal rat. J Neurosci 18:6558-6567.

Burstein R, Dado RJ, Giesler GJ (1990) The cells of origin of the spino-
A

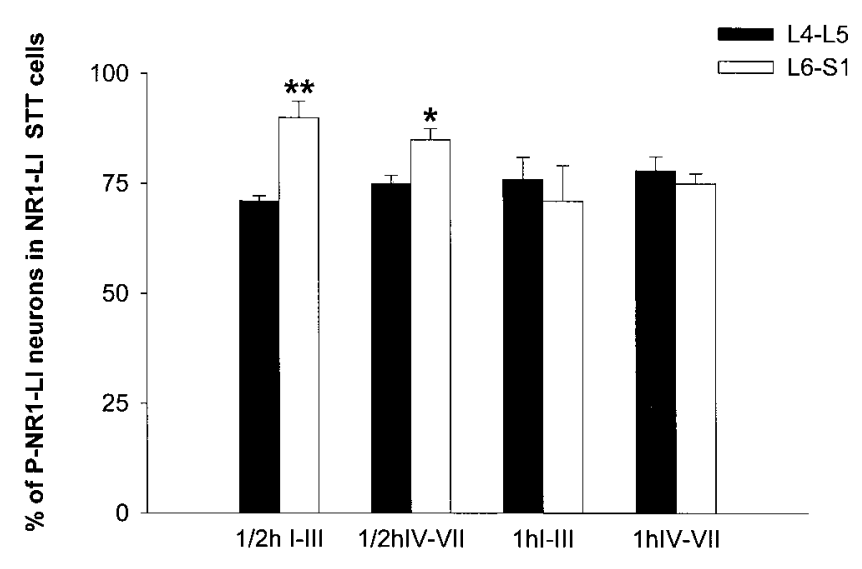

B

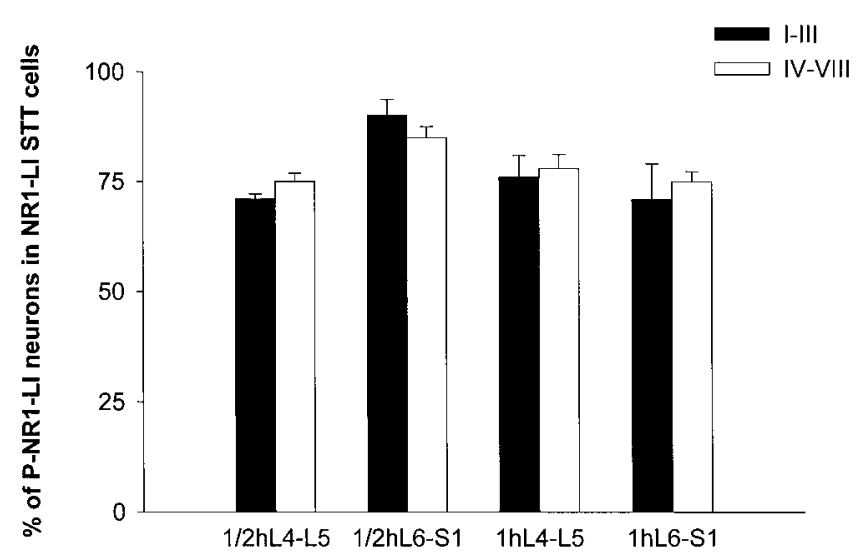

Figure 8. $A$, Bar graph showing the proportion of phospho-NR1-LI STT cells in laminae I-VII in the $\mathrm{L}_{4}-\mathrm{L}_{5}$ and $\mathrm{L}_{6}-\mathrm{S}_{1}$ segments on the CAP injection side $1 / 2$ and $1 \mathrm{hr}$ after CAP injection. The proportion of phosphoNR1-LI STT cells in the $\mathrm{L}_{6}-\mathrm{S}_{1}$ segments was higher than that in the $\mathrm{L}_{4}-\mathrm{L}_{5}$ segments on the side ipsilateral to the CAP injection in the 30 min group but was not different at $60 \mathrm{~min}$. $B$, Bar graph showing the proportion of phospho-NR1-LI STT cells in laminae I-III and laminae IV-VII. There were no significant differences in the proportions of phospho-NR1-LI STT cells at 30 and 60 min after CAP injection. ${ }^{*} p<0.05 ;{ }^{*} p<0.01$.

thalamic tract of the rat: a quantitative reexamination. Brain Res 511:329-337.

Cerne R, Jiang M, Randic M (1992) Cyclic adenosine 3'5'-monophosphate potentiates excitatory amino acid and synaptic responses of rat spinal dorsal horn neurons. Brain Res 596:111-123.

Cerne R, Rusin KI, Randic M (1993) Enhancement of the $N$-methyl-Daspartate response in spinal dorsal horn neurons by cAMP-dependent protein kinase. Neurosci Lett 161:124-128. 
Chen L, Huang LY (1991) Sustained potentiation of NMDA receptormediated glutamate responses through activation of protein kinase $\mathrm{C}$ by a mu opioid. Neuron 7:319-326.

Chen L, Huang LY (1992) Protein kinase C reduces $\mathrm{Mg}^{2+}$ block of NMDA-receptor channels as a mechanism of modulation. Nature 356:521-523.

Christie JM, Wenthold RJ, Monaghan DT (1999) Insulin causes a transient tyrosine phosphorylation of NR2A and NR2B NMDA receptor subunits in rat hippocampus. J Neurochem 72:1523-1528.

Commons KG, van Bockstaele EJ, Pfaff DW (1999) Frequent colocalization of my opioid and NMDA-type glutamate receptors at postsynaptic sites in periaqueductal gray neurons. J Comp Neurol 408:549-559.

Davies SN, Lodge D (1987) Evidence for involvement of $N$-methylaspartate receptors in "wind-up" of class 2 neurones in the dorsal horn of the rat. Brain Res 424:402-406.

Dickenson AH, Sullivan AF (1987) Evidence for a role of the NMDA receptor in the frequency dependent potentiation of deep rat dorsal horn nociceptive neurons following $\mathrm{C}$ fibre stimulation. Neuropharmacology 26:1235-1238

Dingledine R, Borges K, Bowie D, Traynelis SF (1999) The glutamate receptor ion channels. Pharmacol Rev 51:7-61.

Dougherty PM, Willis WD (1991) Enhancement of spinothalamic neuron responses to chemical and mechanical stimuli following combined microiontophoretic application of $N$-methyl-D-aspartic acid and substance $\mathrm{P}$. Pain 47:85-93.

Dougherty PM, Willis WD (1992) Enhanced responses of spinothalamic tract neurons to excitatory amino acids accompany capsaicin-induced sensitization in the monkey. J Neurosci 12:83-394.

Dougherty PM, Palecek J, Paleckova V, Sorkin LS, Willis WD (1992a) The role of NMDA and non-NMDA excitatory amino acid receptors in the excitation of primate spinothalamic tract neurons by mechanical, chemical, thermal, and electrical stimuli. J Neurosci 12:3025-3041.

Dougherty PM, Sluka KA, Sorkin LS, Westlund KN, Willis WD (1992b) Neural changes in acute arthritis in monkeys. I. Parallel enhancement of responses of spinothalamic tract neurons to mechanical stimulation and excitatory amino acids. Brain Res Rev 17:1-13.

Dougherty PM, Palecek J, Paleckova V, Willis WD (1994) Neurokinin 1 and 2 antagonists attenuate the responses and NK1 antagonists prevent the sensitization of primate spinothalamic tract neurons after intradermal capsaicin. J Neurophysiol 72:1464-1475.

Ehlers MD, Tingley WG, Huganir RL (1995) Regulated subcellular distribution of the NR1 subunit of the NMDA receptor. Science 269:1734-1737.

Furuyama T, Kiyama H, Sato K, Park HT, Maeno H, Takagi H, Tohyama M (1993) Region-specific expression of subunits of iontropic glutamate receptors (AMPA-type, KA-type and NMDA receptors) in the rat spina cord with special reference to nociception. Mol Brain Res 18:141-151.

Gamse R, Molnar A, Lembeck F (1979) Substance P release from spinal cord slices by capsaicin. Life Sci 25:629-636.

Gybels JM, Sweet WH (1989) Neurosurgical treatment of persistent pain. Basel: Karger.

Haley JE, Sullivan AF, Dickenson AH (1990) Evidence for spinal $N$-methyl-D-aspartate receptor involvement in prolonged chemical nociception in the rat. Brain Res 518:218-226.

Hatt H (1999) Modification of glutamate receptor channels: molecular mechanisms and functional consequences. Naturwissenschaften 86:177-186.

Hollmann M, Heinemann S (1994) Cloned glutamate receptors. Annu Rev Neurosci 17:31-108.

Ishii T, Moriyoshi K, Sugihara H, Sakurada K, Kadotani H, Yokoi M, Akazawa C, Shigemoto R, Mizuno N, Masu M, Nakanishi S (1993) Molecular characterization of the family of the $N$-methyl-D-aspartate receptor subunits. J Biol Chem 268:2836-2843.

LaMotte RH, Shain CN, Simone DAS, Tsai EF (1991) Neurogenic hyperalgesia: psychophysical studies of underlying mechanisms. J Neurophysiol 66:190-211.

LaMotte RH, Lundberg LE, Torebjörk HE (1992) Pain, hyperalgesia and activity in nociceptive $\mathrm{C}$ units in humans after intradermal injection of capsaicin. J Physiol (Lond) 448:748-764.

Laurie DJ, Putzke J, Zieglgansberger W, Seeburg PH, Tolle TR (1995) The distribution of splice variants of the NMDAR1 subunit mRNA in adult rat brain. Mol Brain Res 32:94-108.

Leonard AS, Hell JW (1997) Cyclic AMP-dependent protein kinase and protein kinase $\mathrm{C}$ phosphorylate $N$-methyl-D-aspartate receptors at different sites. J Biol Chem 272:12107-12115.

Li P, Zhuo M (1998) Silent glutamatergic synapses and nociception in mammalian spinal cord. Nature 393:695-698.

Lin Q, Peng YB, Willis WD (1996) Possible role of protein kinase C in the sensitization of primate spinothalamic tract neurons. J Neurosci 16:3026-3034.

Lin Q, Peng YB, Wu J, Willis WD (1997a) Involvement of cGMP in nociceptive processing by and sensitization of spinothalamic neurons in primates. J Neurosci 17:3293-3302.

Lin Q, Wu J, Willis WD (1997b) The effects of protein kinase A activation on the responses of primate spinothalamic neurons to mechanical and thermal stimuli. Soc Neurosci Abstr 23:2357.

Lin Q, Wu J, Cui M, Willis WD (1998) Protein kinase A sensitizes primate spinothalamic tract neurons by influencing spinal excitatory and inhibitory amino acid receptors. Soc Neurosci Abstr 24:637.

Liu H, Wang H, Sheng M, Jan LY, Jan YN, Basbaum AI (1994) Evidence for presynaptic $N$-methyl-D-aspartate autoreceptors in the spinal cord dorsal horn. Proc Natl Acad Sci USA 91:8383-83387.

Mammen AL, Kameyama, K, Roche KW, Huganir RL (1997) Phosphorylation of the alpha-amino-3-hydroxy-5-methylisoxazole4-proprionic acid receptor GluR1 subunit by calcium/calmodulin-dependent kinase I IJ Biol. Chem 272:32528-32533.

Mori H, Mishina M (1995) Structure and function of the NMDA receptor channel. Neuropharmacology 34:1219-1237.

Nagy I, Maggi CA, Dray A, Woolf CJ, Urban L (1993) The role of neurokinin and $N$-methyl-D-aspartate receptors in synaptic transmission from capsaicin-sensitive primary afferents in the rat spinal cord in vitro. Neuroscience 52:1029-1037

Neugebauer V, Chen PS, Willis WD (1999) Role of metabotropic glutamate receptor subtype mGluR1 in brief nociception and central sensitization of primate STT cells. J Neurophysiol 82:272-282.

Paxinos G, Watson C (1986) The rat brain in stereotaxic coordinates, Ed 2. New York: Academic.

Randic M, Hecimovic H, Ryu PD (1990) Substance P modulates glutamate-induced currents in acutely isolated rat spinal dorsal horn neurones. Neurosci Lett 117:74-80.

Raymond LA, Tingley WG, Blackstone CD, Roche KW, Huganir RL (1994) Glutamate receptor modification by protein phosphorylation. J Physiol (Paris) 88:181-192.

Ren K, Dubner R (1993) NMDA receptor antagonists attenuate mechanical hyperalgesia in rats with unilateral inflammation of the hindpaw. Neurosci Lett 163:22-26.

Ren K, Hylden JL, Williams GM, Ruda MA, Dubner R (1992a) The effects of a non-competitive NMDA receptor antagonist, MK-801, on behavioral hyperalgesia and dorsal horn neuronal activity in rats with unilateral inflammation. Pain 50:331-344.

Ren K, Williams GM, Hylden JL, Ruda MA, Dubner R (1992b) The intrathecal administration of excitatory amino acid receptor antagonists selectively attenuated carrageenan-induced behavioral hyperalgesia in rats. Eur J Pharmacol 219:235-243.

Rivot JP, Sousa A, Montagne-Clavel J, Besson JM (1999) Nitric oxide (NO) release by glutamate and NMDA in the dorsal horn of the spinal cord: an in vivo electrochemical approach in the rat. Brain Res 821:101-110.

Rostas JA, Brent VA, Voss K, Errington ML, Bliss TV, Gurd JW (1996) Enhanced tyrosine phosphorylation of the $2 \mathrm{~B}$ subunit of the $N$-methylD-aspartate receptor in long-term potentiation. Proc Natl Acad Sci USA 93:10452-10456.

Rusin KI, Ryu PD, Randic M (1992) Modulation of excitatory amino acid responses in rat dorsal horn neurons by tachykinins. J Neurophysiol 68:265-286.

Rusin KI, Bleakman, D, Chard PS, Randic M, Miller RJ (1993) Tachykinins potentiate $N$-methyl-D-aspartate responses in acutely isolated neurons from the dorsal horn. J Neurochem 60:952-960.

Simone DA, Sorkin LS, Oh U, Chung JM, Owens C, LaMotte RH, Willis WD (1991) Neurogenic hyperalgesia: central neural correlates in responses of spinothalamic tract neurons. J Neurophysiol 66:228-246.

Sluka KA (1997) Blockade of calcium channels can prevent the onset of secondary hyperalgesia and allodynia induced by intradermal injection of capsaicin in rats. Pain 71:157-164.

Sluka KA, Westlund KN (1992) An experimental arthritis in rats: dorsal horn aspartate and glutamate increases. Neurosci Lett 145:141-144.

Sluka KA, Westlund KN (1993a) Spinal cord amino acid release and content in an arthritis model: the effects of pretreatment with nonNMDA, NMDA, and NK1 receptor antagonists. Brain Res 627:89-103.

Sluka KA, Westlund KN (1993b) Behavioral and immunohistochemical changes in an experimental arthritis model in rats. Pain 55:367-377.

Sluka KA, Willis WD (1998) Increased spinal release of excitatory amino acids following intradermal injection of capsaicin is reduced by a protein kinase $\mathrm{G}$ inhibitor. Brain Res 798:281-286.

Sluka KA, Jordan HH, Willis WD, Westlund KN (1994) Differential effects of $N$-methyl-D-aspartate (NMDA) and non-NMDA receptor antagonists on spinal release of amino acids after development of acute arthritis in rats. Brain Res 664:77-84.

Sluka KA, Rees H, Chen PS, Tsuruoka M, Willis WD (1997) Inhibitors of G-proteins and protein kinases reduce the sensitization to mechanical stimulation and the desensitization to heat of spinothalamic tract neurons induced by intradermal injection of capsaicin in the primate. Exp Brain Res 115:15-24.

Sorkin LS, McAdoo DJ (1993) Amino acids and serotonin are released into the lumbar spinal cord of the anesthetized cat following intradermal capsaicin injections. Brain Res 607:89-98.

Sorkin LS, Westlund KN, Sluka KA, Dougherty PM, Willis WD (1992) Neural changes in acute arthritis in monkeys. IV. Time-course of amino acid release into the lumbar dorsal horn. Brain Res Rev 17:39-50.

Sugihara H, Moriyoshi K, Ishii T, Masu M, Nakanishi S (1992) Structures and properties of seven isoforms of the NMDA receptor generated by alternative splicing. Biochem Biophys Res Commun 185:826-832.

Takahashi Y, Nakajima Y, Sakamoto T (1994) Dermatome mapping in the 
rat hindlimb by electrical stimulation of the spinal nerves. Neurosci Lett 168:85-88.

Tingley WG, Ehlers MD, Kameyama K, Doherty C, Ptak JB, Riley CT, Huganir RL (1997) Characterization of protein kinase A and protein kinase $\mathrm{C}$ phosphorylation of the $N$-methyl-D-aspartate receptor NR1 subunit using phosphorylation site-specific antibodies. J Biol Chem 272:5157-5166.

Tominaga M, Caterina MJ, Malmberg AB, Rosen TA, Gilbert H, Skinner K, Raumann BE, Basbaum AI, Julius D (1998) The cloned capsaicin receptor integrates multiple pain-producing stimuli. Neuron 21:531-543.

Torebjörk HE, Lundberg LE, LaMotte RH (1992) Central changes in processing of mechanorecpetive input in capsaicin-induced secondary hyperalgesia in humans. J Physiol (Lond) 448:765-780.

Wang YT, Yu XM, Salter MW (1996) $\mathrm{Ca}^{2+}$-independent reduction of $N$-methyl-D-aspartate channel activity by protein tyrosine phosphatase. Proc Natl Acad Sci USA 93:1721-1725.

Willis WD (1985) The pain system. Basel: Karger.

Willis WD, Coggeshall RE (1991) Sensory mechanisms of the spinal cord. New York: Plenum.
Wood MW, VanDongen HMA, VanDongen AMJ (1995) Structural conservation of ion conduction pathways in $\mathrm{K}$ channel and glutamate receptors. Proc Natl Acad Sci USA 92:4882-4886.

Ye Z, Westlund KN (1996) Ultrastructural localization of glutamate receptor subunits (NMDAR1, AMPA GluR1 and GluR2/3) and spinothalamic tract cells. NeuroReport 7:2581-2585.

Yu XM, Salter MW (1999) Src, a molecular switch governing gain control of synaptic transmission mediated by $N$-methyl-D-aspartate receptors. Proc Natl Acad Sci USA 96:7697-7704.

Yu XM, Askalan R, Keill GJ, Salter MW (1997) NMDA channel regulation by channel-associated protein tyrosine kinase Src. Science 275:674-678.

Zheng X, Zhang L, Wang AP, Bennett MV, Zukin RS (1999) Protein kinase C potentiation of $N$-methyl-D-aspartate receptor activity is not mediated by phosphorylation of $N$-methyl-D-aspartate receptor subunits. Proc Natl Acad Sci USA 96:15262-15267.

Zou XJ, Lin Q, Willis WD (1999) Enhanced phosphorylation of the NMDA NR1 subunit on spinal dorsal horn neurons following intradermal injection of capsaicin in rats. Soc Neurosci Abstr 25:1980. 